\title{
Studies on Synthesis and Characterization of Magnesia Based Refractory Aggregates Developed from Indian Magnesite
}

\author{
Manas Kamal Haldar*, Chandrima Ghosh, Arup Ghosh \\ Refractories Division, CSIR-Central Glass \& Ceramic Research Institute, Kolkata, India \\ Email: "manashaldar@cgcri.res.in
}

Received July 2014

\begin{abstract}
The present work intends to study the properties of magnesia based refractory aggregates developed from Indian magnesite by changing lime/silica ratio. The material has been sintered in the temperature range of $1550^{\circ} \mathrm{C}-1700^{\circ} \mathrm{C}$. The sintered samples are characterized in terms of bulk density, apparent porosity, true density, percentage densification, mechanical, thermo-mechanical properties like cold modulus of rupture, hot modulus of rupture and thermal shock resistance and structural properties by XRD. The developed microstructures at different temperatures are studied through FESEM study and compositional analysis of the developed phases is done by EDX study.
\end{abstract}

\section{Keywords}

Sintering, Magnesite, Microstructure, Thermo-Mechanical Properties, Refractories

\section{Introduction}

Magnesia refractories are prepared in India mainly from naturally occurring magnesite. It is an important material to the refractory industries. The importance of this basic oxide based refractories have increased considerably over the years due to the rapid expansion and technology changes of iron and steel industry, cement and glass industries. The main reasons of its success are high melting point $\left(\sim 2800^{\circ} \mathrm{C}\right)$ and its excellent resistance to attack by iron oxide, alkalis and high lime containing slags at working temperature of steel melting furnaces [1] $\left(1700^{\circ} \mathrm{C}\right)$. Unlike its rivals (e.g. lime and dolomite), it does not suffer from hydration and is not toxic.

Though India has vast resources of natural magnesite, the refractory industries are mostly dependent on the imported magnesia. This is due to the fact that Indian magnesite is rich in impurities, mainly $\mathrm{SiO}_{2}, \mathrm{Fe}_{2} \mathrm{O}_{3}, \mathrm{CaO}$ which form low melting phases at elevated temperature causing poor refractory properties, e.g. high temperature strength, corrosion resistance. One of the most important \& critical parameters in magnesia refractory is $\mathrm{CaO} / \mathrm{SiO}_{2}$ ratio [2] which significantly affects the formation of low melting phases. In this background, an attempt has been made to synthesis and study the properties of magnesia based refractory aggregates (by changing the $\mathrm{CaO} / \mathrm{SiO}_{2}$ ratio) developed from lean grade Indian magnesite.

\footnotetext{
${ }^{*}$ Corresponding author.
}

How to cite this paper: Haldar, M.K., Ghosh, C. and Ghosh, A. (2014) Studies on Synthesis and Characterization of Magnesia Based Refractory Aggregates Developed from Indian Magnesite. Journal of Materials Science and Chemical Engineering, 2, 1-8. http://dx.doi.org/10.4236/msce.2014.210001 


\section{Experimental}

Natural Indian magnesite of Salem district in Tamilnadu (supplied by erstwhile Burn Standard Co. Ltd., presently SAIL Refractory Co. Ltd, India) was selected for the present study. The $\mathrm{CaCO}_{3}$ of S.D. Fine Chemical Limited, India was selected for changing the $\mathrm{CaO} / \mathrm{SiO}_{2}$ ratio of the batches. The chemical analysis of the magnesite, as received, is delineated in Table 1. The analysis was done by standard wet chemical procedure. $0.25 \mathrm{~g}$ of the solid powdered sample was taken into a platinum crucible and the sample was thoroughly mixed with borax sodium carbonate fusion mixture and melted at around $900^{\circ} \mathrm{C}$ for $1 \mathrm{~h}$. After melting, the mass was cooled down and digested with nitric acid to obtain a solution. $\mathrm{Fe}_{2} \mathrm{O}_{3}$ and $\mathrm{TiO}_{2}$ were measured by colorimetric method. MgO, $\mathrm{Al}_{2} \mathrm{O}_{3}, \mathrm{CaO}$ were determined by complexometric method using EDTA solution. $\mathrm{Na}_{2} \mathrm{O}$ and $\mathrm{K}_{2} \mathrm{O}$ were measured by flame photometry using hydrofluoric acid and perchloric acid digested magnesite solution. $\mathrm{SiO}_{2}$ was measured by gravimetric method.

The structural characterization of the sintered aggregates in terms of phase identification and evaluation of crystal structure parameters like crystallite size, lattice strain, lattice parameters, unit cell volume etc was performed by X-ray diffraction technique. The XRD patterns of the samples were recorded in X'pert Pro MPD diffractometer (PANalytical) by X'Celerator operating at $40 \mathrm{kV}$ and $30 \mathrm{~mA}$, using Ni-filtered CuK $\alpha$ radiation. The XRD data were recorded with step size of $0.05^{\circ}(2 \theta)$, step time of $75 \mathrm{sec}$, from $10^{\circ}$ to $90^{\circ}$. The magnesite ores were crushed in a jaw crusher and hammered to pass through 100 mesh sieve. These powders were mixed with $\mathrm{CaCO}_{3}$ to have a mole ratio of $\mathrm{CaO}: \mathrm{SiO}_{2}=2: 1$. The batch was attrition milled in attritor mill with isopropyl alcohol for $1 \mathrm{~h}$. The slurry thus obtained was dried at $50^{\circ} \mathrm{C} \pm 2^{\circ} \mathrm{C}$ in a laboratory oven for $2 \mathrm{~h}$ and passed through 100 mesh sieve to get the desired powder. Powdered sample was mixed with 5\% (w/v) of polyvinyl alcohol solution as binder and subsequently granulated by sieving and uni-axially pressed at 140 MPa pressure into pellets of $2.5 \mathrm{~cm}$ dia and $1 \mathrm{~cm}$ height for densification studies and bars of $80 \mathrm{~mm} \times 8 \mathrm{~mm} \times 8 \mathrm{~mm}$ for thermo-mechanical and mechanical studies and few bars were cold iso-statically pressed at $140 \mathrm{MPa}$ for thermal shock studies. All the pressed samples were dried at $110^{\circ} \mathrm{C} \pm 5^{\circ} \mathrm{C}$ and sintered in the temperature range of $1550^{\circ} \mathrm{C}-1700^{\circ} \mathrm{C}$ with $2 \mathrm{~h}$ of soaking at the peak temperature. Sintered samples were characterized in terms of bulk density, apparent porosity, closed porosity, true density, relative density (percentage densification). The bulk density and apparent porosity were measured by water displacement method using Archimedes' principle. True density was measured with powdered samples in a pycnometer bottle. From these two values, percentage densification of the sintered samples was measured. Closed porosity was measured by subtracting apparent porosity values from total porosity. The linear shrinkage of the sintered samples was measured using digital slide calipers. Crystalline phases of the sintered samples were identified from XRD patterns. Percentages of crystalline phases were estimated for the samples from X-ray diffraction line profile analysis using Rietveld method [1] by X'Pert High Score Plus software (PANalytical). The flexural strength at room temperature (cold MOR) of the sintered rectangular bars was measured by three point bending method using an Instron-1185 universal testing machine. The span of the bars was $40 \mathrm{~mm}$ and the cross head speed was $0.5 \mathrm{~mm} \cdot \mathrm{min}^{-1}$. The high temperature modulus of rupture strength was measured at $1300^{\circ} \mathrm{C}$ by an instrument supplied by Stedfast International Company Limited,

Table 1. Chemical analysis of as received magnesite.

\begin{tabular}{ccc}
\hline Constituents & $\mathbf{W t} \%$ & Wt \% (loss free basis) \\
\hline $\mathrm{SiO}_{2}$ & 2.44 & 4.8 \\
$\mathrm{Al}_{2} \mathrm{O}_{3}$ & 0.17 & 0.34 \\
$\mathrm{Fe}_{2} \mathrm{O}_{3}$ & 0.24 & 0.48 \\
$\mathrm{TiO}_{2}$ & 0.02 & 0.4 \\
$\mathrm{CaO}$ & 1.41 & 2.79 \\
$\mathrm{MgO}$ & 45.68 & 90.49 \\
$\mathrm{Na}$ & 0.08 & 0.16 \\
$\mathrm{~K}_{2} \mathrm{O}$ & 0.05 & 0.99 \\
$\mathrm{~L} . \mathrm{O} . \mathrm{I}$. & 49.52 & - \\
\hline
\end{tabular}


India. The test was done under three point loading on a span of $45 \mathrm{~mm}$ during testing. The rate of temperature rise was maintained at $5^{\circ} \mathrm{C} / \mathrm{min}$ and samples were allowed a soaking period of $30 \mathrm{~min}$ at test temperatures. The load then applied at a rate of $0.5 \mathrm{~mm} \cdot \mathrm{min}^{-1}$. Thermal shock resistance of the sintered samples was measured using the following test method. The sintered rectangular bars were heated up to $1200^{\circ} \mathrm{C}$ with a soaking period of 30 minutes initially. Then they were exposed to normal room temperature air (without any draught in the surroundings) for 10 minutes and again put into furnace for 10 minutes. These complete one cycle. These samples are put up to ten cycles. The samples of second, fourth, sixth, eighth and tenth cycle were examined by measuring the retained flexural strength through three point bending method using an Instron-1185 universal testing machine. The span was maintained at $45 \mathrm{~mm}$ and the cross head speed was $0.5 \mathrm{~mm} \cdot \mathrm{min}^{-1}$. Microstructure evaluation of the sintered samples was done by scanning electron microscopy (Make Zeiss, Germany) on the polished surface after thermal etching. Elemental analysis was done by EDX technique using sintered polished samples.

\section{Results \& Discussion}

\subsection{Characterization of Sintered Aggregates}

\subsubsection{Physical \& Physico-Chemical Properties}

Figure 1 shows the effect of sintering temperature on the bulk density (BD) and apparent Porosity (AP) of the sintered samples. The sample shows increase in the bulk density with increasing sintering temperature till $1650^{\circ} \mathrm{C}$. At $1700^{\circ} \mathrm{C}$, there is a slight decrease in BD. In case of AP, it is highest at $1550^{\circ} \mathrm{C}$ and lowest at $1600^{\circ} \mathrm{C}$. After $1600^{\circ} \mathrm{C}$ it slightly increases at $1650^{\circ} \mathrm{C}$ and remains the same at $1700^{\circ} \mathrm{C}$. Figure 2 depicts the effect of

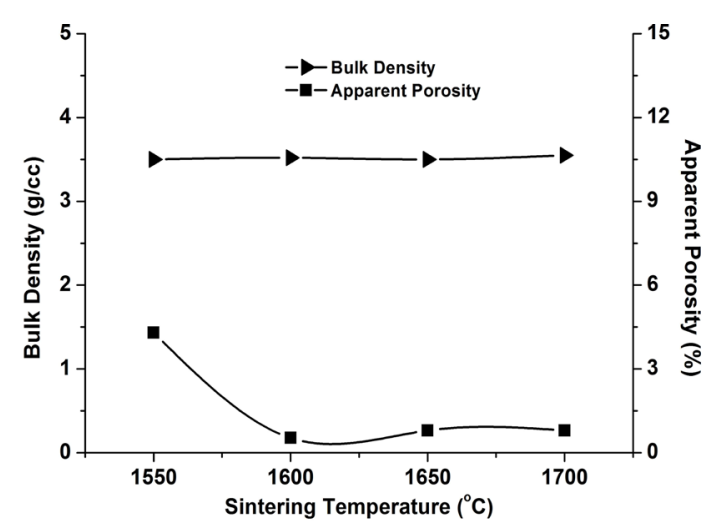

Figure 1. Variation in bulk density and apparent porosity with sintering temperature.

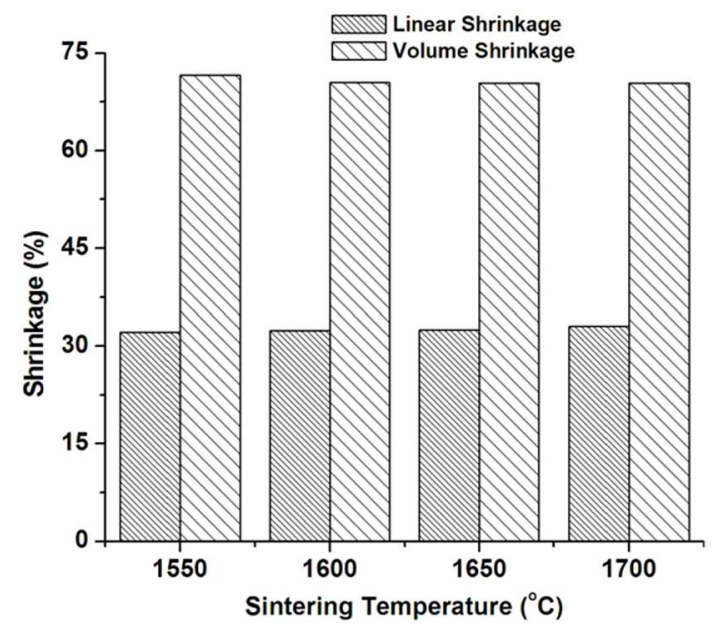

Figure 2. Variation in linear shrinkage and volume shrinkage with sintering temperature. 
sintering temperature on the linear shrinkage and volume shrinkage of the sintered magnesia samples. Linear shrinkage is almost same throughout the temperature range and volume shrinkage is highest at $1550^{\circ} \mathrm{C}$. The change in true density and densification with sintering temperature is shown in Figure 3. True density varies in the range of 3.5 to 3.55 and densification is above $90 \%$ for all the samples sintered in between $1550^{\circ} \mathrm{C}-1700^{\circ} \mathrm{C}$ with highest densification achieved at $1650^{\circ} \mathrm{C}$. This result later corroborates the HMOR value which is also the highest at $1650^{\circ} \mathrm{C}$. Figure 4 shows the change in total porosity and closed porosity with sintering temperature. It is seen that in both the cases same trend is followed. Both the porosities are the lowest at $1650^{\circ} \mathrm{C}$ which reveals the development of compact microstructure as observed in scanning electron photomicrographs.

\subsubsection{Mineralogical Properties}

The powder X-ray diffraction pattern of the sample sintered at $1650^{\circ} \mathrm{C}$ is shown in Figure 5. Examination of the $\mathrm{CaO}-\mathrm{MgO}-\mathrm{SiO}_{2}$ phase diagram [3] shows that silicate phases that exist with $\mathrm{C} / \mathrm{S}$ ratios between 0 and 1 are forsterite $\left(\mathrm{M}_{2} \mathrm{~S}\right)$ and monticellite (CMS), and between 1.5 and 2 are dicalcium silicate $\left(\mathrm{C}_{2} \mathrm{~S}\right)$ and merwinite [4]. This proves that it is the $\mathrm{C} / \mathrm{S}$ ratio and not simply the amount of $\mathrm{CaO}$ present that determines the silicate phases [4] present. Table 2 shows the change in percentage of periclase phase with sintering temperature. Rietveld refinement analysis helps us in determining how the observed values fit with the theoretical values [5] [6]. Rietveld method is a full-pattern fit method. This is basically a non-linear least square method. The measured profile is obtained by the variation of many parameters resulting in minimization of the difference between the two

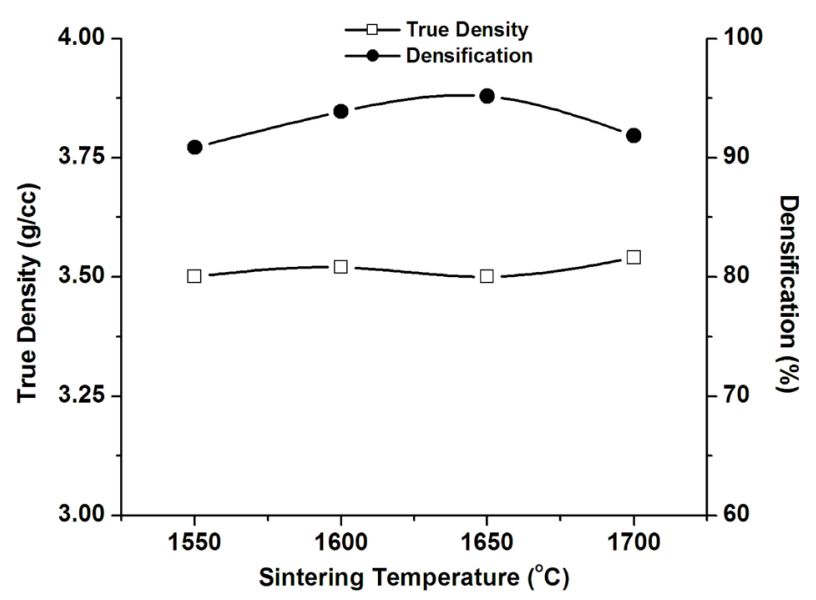

Figure 3. Variation in true density and densification with sintering temperature.

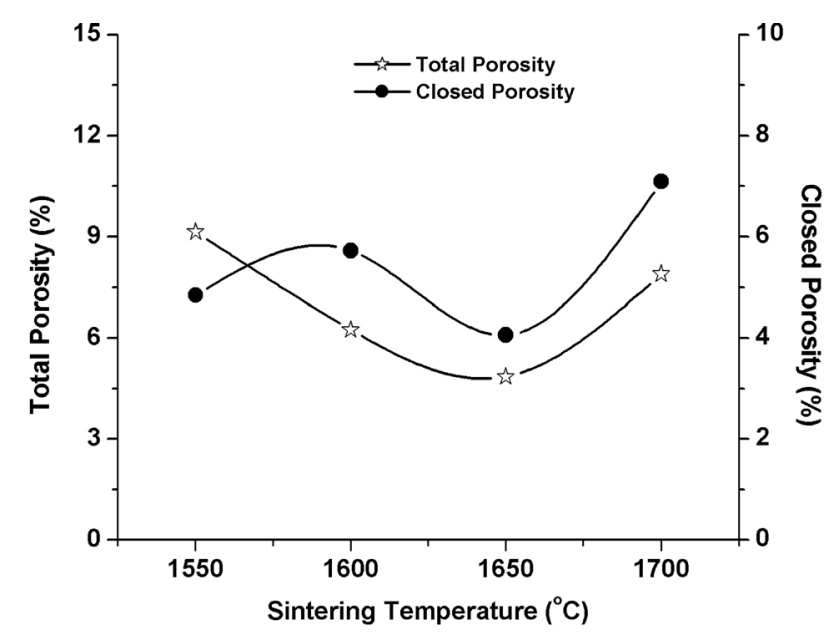

Figure 4. Variation in total porosity and closed porosity with sintering temperature. 


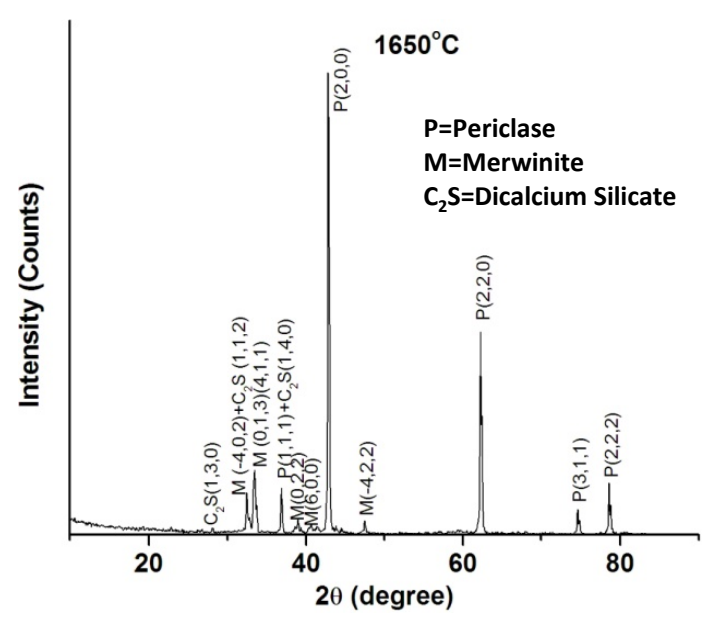

Figure 5. X-Ray diffraction of sample sintered at $1650^{\circ} \mathrm{C}$.

Table 2. Variation in Periclase content with increasing sintering temperature.

\begin{tabular}{cc}
\hline Sample Sintering Temperature $\left({ }^{\circ} \mathbf{C}\right)$ & Periclase (\%) \\
\hline 1550 & 65.9 \\
1600 & 71.8 \\
1650 & 74.6 \\
1700 & 76.4 \\
\hline
\end{tabular}

profiles and the calculated profile is compared and the least square refinements are carried out until the residuals are minimized and best fit is achieved between the entire observed powder diffraction pattern taken as a whole and the entire calculated pattern (based on simultaneously refined models for crystal structures, instrumental factors, diffraction optics effects and other specimen characteristics like lattice parameters, size and strain parameters) as may be desired and can be modeled. Table 3 shows the change in lattice parameters of periclase with sintering temperature. The quality of fit was assessed using various numerical criteria of best fit, namely the profile residual factor $(R p)$, the weighted residual factor $\left(R_{w p}\right)$, the expected residual factor $\left(R_{\text {exp }}\right)$, weightedstatistics $\left(D_{w s}\right)$ and the goodness of fit (GOF) as obtained from Rietveld analysis (all confirming good fit). The values of the reliability parameters of the fit during Rietveld refinement are given in Table 4.

\subsubsection{Mechanical/Thermo Mechanical Properties}

In a multiphase material, mechanical strength depends mainly on the microstructure of the material. In other words, the amount and distribution of the phases play an important role in determining the mechanical strength. Figure 6 shows the effect of sintering temperature on the flexural strength of samples at ambient temperature and $1300^{\circ} \mathrm{C}$. Flexural strength (Cold Modulus of Rupture \& Hot Modulus of Rupture) is measured using the three point bending method. The samples sintered at $1650^{\circ} \mathrm{C}$ show appreciably higher CMOR \& HMOR values than the samples sintered at lower temperature which corroborates the results found for other basic refractories [7]. Figure 7 shows the retained flexural strength of samples at ambient temperature after undergoing different thermal cycles at $1200^{\circ} \mathrm{C}$. It is well known that the origin of thermal stresses is the difference in thermal expansion of various parts of a body under conditions such that free expansion of each small unit of volume cannot take place [8]. The samples show a decreasing trend of retained flexural strength with increasing thermal cycles as expected.

\subsubsection{Micro Structural Characterization}

The inter-relation between microstructure and properties of a material is very important for the deeper understanding of material property and its improvement. The advantage of this correlation is that it may be applied to develop materials with tailor made properties. Figures 8-10 show the FESEM images of the thermally etched 


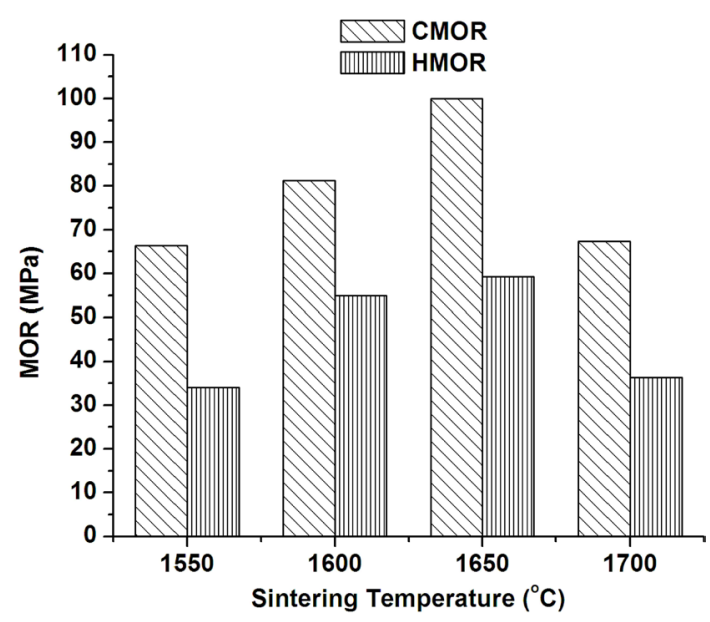

Figure 6. Variation in Cold MOR and Hot MOR with sintering temperature.

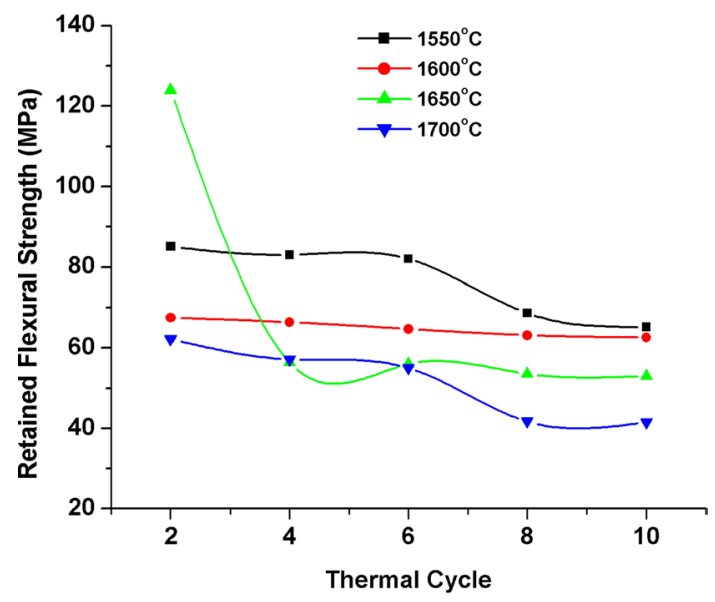

Figure 7. Retained Flexural Strength of samples after different thermal cycles.

Table 3. The values of cell parameters and unit cell volume of periclase phase of samples after sintering at different temperatures.

\begin{tabular}{cc}
\hline Sample Sintering Temperature $\left({ }^{\circ} \mathbf{C}\right)$ & Periclase \\
\hline 1550 & $\mathrm{a}=\mathrm{b}=\mathrm{c}=4.212018 \AA$ \\
1600 & $\mathrm{a}=\mathrm{b}=\mathrm{c}=4.212203 \AA$ \\
1650 & $\mathrm{a}=\mathrm{b}=\mathrm{c}=4.213327 \AA$ \\
1700 & $\mathrm{a}=\mathrm{b}=\mathrm{c}=4.213485 \AA$ \\
\hline
\end{tabular}

Table 4. The values of reliability parameters as obtained by Rietveld analysis of samples after sintering at different temperatures.

\begin{tabular}{ccccccc}
\hline Sample Sintering Temperature $\left({ }^{\circ} \mathbf{C}\right)$ & $\mathbf{R}_{\text {exp }}$ & $\mathbf{R}_{\mathbf{p}}$ & $\mathbf{R}_{\text {wp }}$ & $\mathbf{D}_{\text {st }}$ & $\mathbf{D}_{\text {wst }}$ & GOF \\
\hline 1550 & 14.72158 & 16.23802 & 20.74131 & 0.80825 & 0.74349 & 1.985011 \\
1600 & 14.85615 & 14.65899 & 19.66928 & 0.94398 & 0.78592 & 1.75293 \\
1650 & 14.13249 & 17.23880 & 21.65164 & 1.17287 & 0.68589 & 2.34717 \\
1700 & 11.97883 & 16.30035 & 19.00794 & 0.52933 & 0.61202 & 2.51792 \\
\hline
\end{tabular}




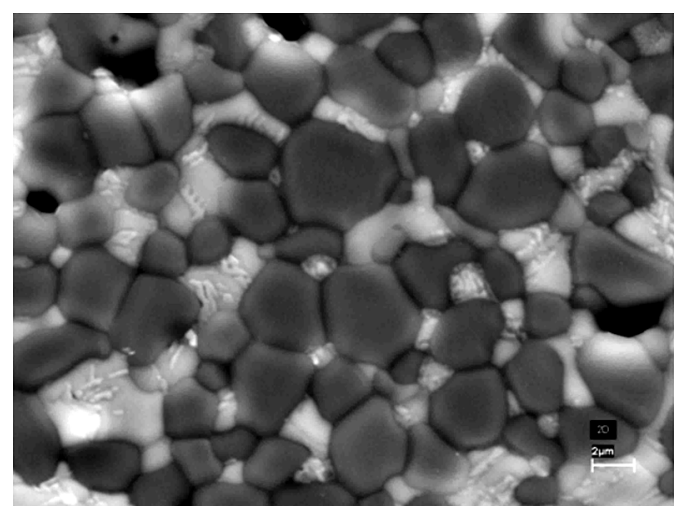

Figure 8. Scanning electron micrograph of sample sintered at $1550^{\circ} \mathrm{C} / 2 \mathrm{~h}$.

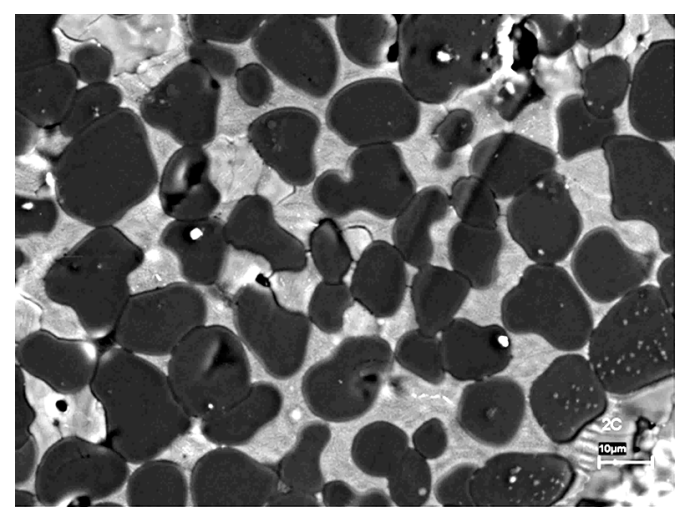

Figure 9. Scanning electron micrograph of sample sintered at $1600^{\circ} \mathrm{C} / 2 \mathrm{~h}$.

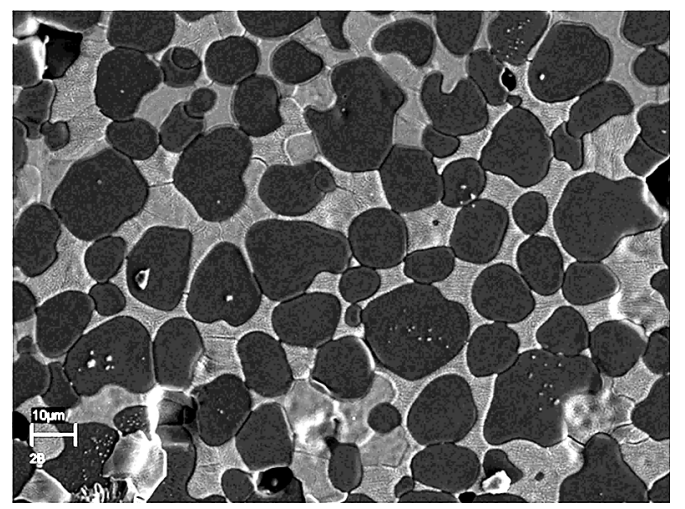

Figure 10. Scanning electron micrograph of sample sintered at $1650^{\circ} \mathrm{C} / 2 \mathrm{~h}$.

polished surfaces of the samples sintered at different temperatures for $2 \mathrm{~h}$. In case of all the samples sintered in the temperature range of $1550^{\circ} \mathrm{C}$ to $1700^{\circ} \mathrm{C}$, it is found that microstructure mainly consists of subrounded to rounded periclase grains $(\mathrm{P})$ with the bonding material in between the grains [9]. These periclase grains are dark in color and most of them are surrounded by siliceous bond [10]. Very few periclase grains are directly bonded. It is being also found that the silicate bond phases are concentrated mainly in small triangular pockets, formed close to periclase grains. The EDX analysis (Figure 11) of the samples reveals this interconnected phases are mainly $\mathrm{C}_{2} \mathrm{~S}$ with a small amount of merwinite. From EDX it is observed that at $1650^{\circ} \mathrm{C}$, the amount of $\mathrm{C}_{2} \mathrm{~S}$ phase is more which gives support to the HMOR results which is highest at $1650^{\circ} \mathrm{C}$. 

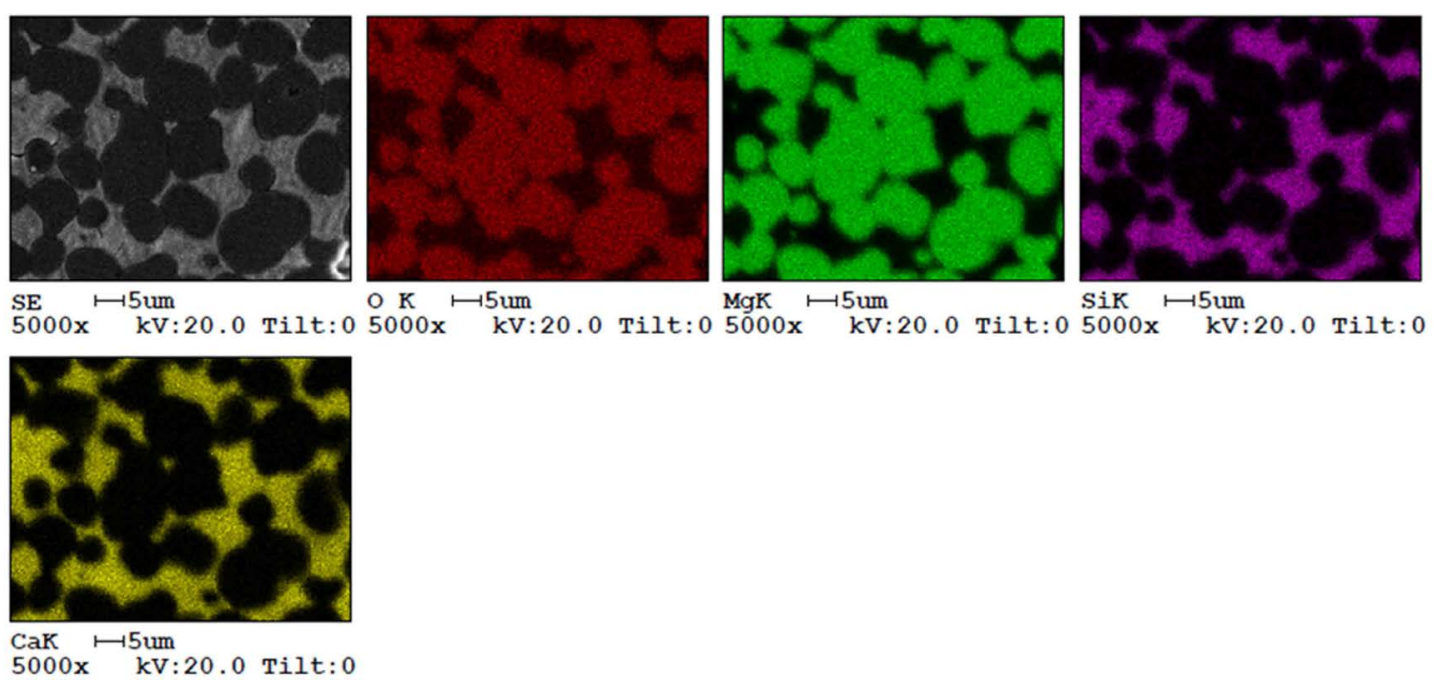

Figure 11. EDX Analysis (Elemental Mapping) of sample sintered at $1650^{\circ} \mathrm{C}$.

\section{Conclusion}

The present investigation demonstrates that Indian natural magnesite can be sintered by changing $\mathrm{C} / \mathrm{S}$ ratio to 2:1 in the temperature range of $1550^{\circ} \mathrm{C}-1700^{\circ} \mathrm{C}$ with highest $\mathrm{BD}$ of $3.33 \mathrm{~g} / \mathrm{cc}$. The hot modulus of rupture values of sintered samples is considerably high. The microstructure reveals that the matrix consists of mainly periclase grains and $\mathrm{C}_{2} \mathrm{~S}$ accompanied by merwinite as minor phase. Presence of $\mathrm{C}_{2} \mathrm{~S}$ phase (desirable high temperature phase) helps to increase the hot MOR value.

\section{Acknowledgements}

The authors wish to thank the Director, CSIR-CGCRI for his kind permission to publish this paper. The authors are also thankful to Ministry of Mines, Govt. of India for providing financial assistance in carrying out this work.

\section{References}

[1] Serry, M.A., Hammad, S.M. and Zawrah, M.F.M. (1997) Densification and Microstructure of Refractory Periclase Grains. Interceram, 46, 430-435.

[2] Lee, W.E. and Rainforth, W.M. (1994) Ceramic Microstructures Property Control by Processing. Chapman \& Hall, UK.

[3] Steijn, R.P. (1963) Sliding and Wear in Ionic Crystals. Journal of Applied Physics, 34, 419-428. http://dx.doi.org/10.1063/1.1702624

[4] Staut, R. (1972) Effects of the Lime-Silica Ratio on the Physical Properties of Magnesia-Chrome Ore Composition. Journal of the American Ceramic Society, 51, 901-905.

[5] Young, R.A. (1993) The Rietveld Method. Oxford University Press.

[6] De la Torre, A.G., Valle, F.J. and De Aza, A.H. (2006) Direct Mineralogical Composition of a MgO-C Refractory Material Obtained by Rietveld Methodology. Journal of the European Ceramic Society, 26, 2587-2592. http://dx.doi.org/10.1016/j.jeurceramsoc.2005.05.005

[7] Rigby, G.R. (1970) Mechanical Properties of Basic Bricks I. A Survey of the Magnesia-Chrome System. Transactions and Journal of the British Ceramic Society, 69, 189-198.

[8] Timoshenko, S. (1934) Theory of Elasticity. McGraw-Hill Book Co, Inc, New York.

[9] Chaudhuri, M., Kumar, A., Bhadra, A.K. and Banerjee, G. (1990) Sintering and Grain Growth in Indian Magnesites Doped with Titanium Dioxide. Interceram, 39, 26-30.

[10] Lampropoulou, P.G. and Katagas, C.G. (2005) Composition of Periclase \& Calcium-Silicate Phases in Magnesia Refractories Derived from Natural Microcrystalline Magnesite. Journal of the American Ceramic Society, 88, 1568-1574. http://dx.doi.org/10.1111/j.1551-2916.2005.00263.x 